\title{
Emerging Opportunities for 'Design Thinking' to Deliver Sustainable Solutions in the Built Environment
}

\author{
Kimberley Wilson, Queensland University of Technology, Australia \\ Cheryl Desha, Queensland University of Technology, Australia \\ Sam Bucolo, University of Technology Sydney, Australia \\ Evonne Miller, Queensland University of Technology, Australia \\ Charlie Hargroves, Curtin University, Australia
}

\begin{abstract}
Worldwide in the built environment sector, a range of innovations are delivering environmental improvements with mixed success. The authors of this paper argue that a more 'disruptive' form of innovation is needed to transition practices and bring about significant and systemic change within the sector. Critical to this transition is the development of new behaviours and values. In particular, built environment professionals need to become active change agents in cultivating these new behaviours and values through the development of collaborative visions, scenarios, practices and ideas. Within this context, this paper identifies and discusses the critical role that design (in its broadest sense) can play in this process. Drawing on a comprehensive review of literature, the authors highlight a number of transformational opportunities for cross-professional learning and sharing between design and built environment disciplines in achieving environmental innovation (eco-innovation). The paper also considers several design-based concepts that have a potential application in the built environment sector including: design thinking, social innovation (human-centered) and disruptive innovation (transformational) approaches. The research findings will assist in building the capabilities of designers and innovators to create sustainable solutions to global problems, and in supporting the social diffusion of systems-changing ideas in the built environment sector.
\end{abstract}

Keywords: Innovation, Environment, Transformative

\section{Introduction}

$\mathrm{R}$ ecent literature in the field of sustainable development identifies that the need to confront and rapidly respond to a range of unprecedented issues, including climate change and building on progress to date which has had mixed and largely incremental success - with only a few examples of large scale change emerging to date (Von Weizsäcker et al. 2009). Seminal publications such as the Stern Review (Stern 2006) conclude that a priority in this rapid response strategy is a significant reduction in greenhouse gas (GHG) emissions on a global scale.

Worldwide, the built environment sector is responsible for a significant proportion of global GHG emissions: thus, action to minimise GHG contributions in this sector has the potential to lead to large reductions (Smith, Hargroves, and Desha 2010, Built Environment Industry Innovation Council 2012). The State of the Environment 2011 Committee (2011) describes the built environment as the 'human-made surroundings' of our environment, encompassing the supporting infrastructure that enables communities to live, work and play - such as energy, water and transport. It provides the foundations of communities through delivering vital infrastructure and buildings (Sustainable Built Environment National Research Centre 2011). In Australia, the recent introduction of a carbon pricing mechanism has increased pressure on the built environment sector to decrease energy usage and mitigate its GHG emissions (Davis Langdon 2012).

It is clear that a holistic and systemic approach is necessary in transitioning this sector to low carbon operation. Interdisciplinary, inter-cultural and collaborative efforts are required in diffusing shared visions, scenarios, ideas and enabling solutions. A challenge that is widely accepted in sustainable development literature is to decouple economic growth from environmental pressure (Smith, Hargroves, and Desha 2010). As environmental pressures are generated as a result of a wide range of economic activities, economy-wide reduction efforts are required to address such concerns; however, maintaining economic performance is, of course, a 
dual priority. Decoupling economic growth from environmental pressure and recoupling it with environmental improvements will require significant reorientation across all aspects of our society - including legislation, standards, systems and practices. Although some incremental innovations already exist and are delivering environmental improvements, such as maximising resource efficiency and decreasing energy use - the reality is that these have not yet produced a significant transition to global sustainable development.

Fortunately, design may provide part of the solution. Fry $(2009,55)$ describes the power of design as 'world-shaping' in its force and potentially a 'redirective practice' in developing and deploying strategies for change. Carrillo-Hermosilla, del Río González, and Könnöla $(2009,10)$ agree and describe the design of product and process development as 'an unparalleled window of opportunity to address environmental objectives', both incrementally in minimising negative impacts or radical in changing systems with a focus on positive impact.

Drawing on the perspectives of these authors, and using an interdisciplinary research enquiry approach, this paper identifies and explores a number of key concepts in design literature that have the potential to inform the transition to sustainable development in the built environment sector. This paper discusses what can be learned and shared between design and built environment disciplines to achieve such improvements. Concepts inherent to design, such as environment-led 'eco-innovation', 'design innovation', human-centred 'social innovation', and transformational 'disruptive innovation' are explored - identifying key learnings and insights from design that have the potential to significantly influence (and potentially disrupt) current built environment sector practices.

\section{Transformative Environmental Change}

Considering the ad hoc and highly variable efforts within the built environment sector to reduce environmental pressures, the OECD Innovation Strategy (2009) discusses the merits of a more disruptive form of eco-innovation (environmental innovation), as key to enabling a sustainable transition to a greener economy across the sectors, by radically transforming practice and bringing about systemic change. It is believed that environmental innovation - through the emergence of new green activities, subsequent economic opportunities and enhanced efficiency in the use of natural capital - creates 'win-win synergies' between environmental, economic and social factors (OECD, European Commission, and Nordic Innovation Joint Workshop 2012).

Social and cultural change in the form of new behaviours and values are important elements in this process of disruptive reconfiguration, whether it be the primary objective, an unintended by-product of pursuing a business opportunity (Christensen et al. 2006), or an imperative prerequisite (OECD Innovation Strategy 2009). Critically, a better understanding of the concept of environmental innovation may enable transformation in the built environment sector.

\section{Characteristics of Environmental Innovation (Eco-Innovation)}

The term 'eco-innovation' is described broadly as the application or introduction of new behaviours, ideas, organisational and marketing methods, social and institutional structures, products or processes that contribute to a reduction of environmental burdens (Rennings 2000). Further, it is understood that eco-innovation is evident, whether intended or not, when a reduction in environmental impact occurs (OECD Innovation Strategy 2009). In addition to the broadness of this definition in that unintended environmental benefits may result from innovation that is driven by other goals (such as reducing costs), there is also discussion surrounding the differing views on whether eco-innovation is the creation of something new or simply the implementation of something already existing in a way that results in environmental improvements (Arundel and Kemp 2009). Regardless, eco-innovation is said to contribute to the decoupling of economic growth from environmental degradation (Arundel and Kemp 2009, Hargroves and Smith 2005, Smith, Hargroves, and Desha 2010). 
Rennings (2000) categorises the key driving forces of eco-innovation as technology push (such as energy efficiency), regulatory push (such as standards) and market pull (such as customer demand), arguing that eco-innovation can be organisational, institutional, social or technological in nature. More specifically, Carrillo-Hermosilla, del Río González, and Könnöla (2009) developed a framework consisting of eight equally-weighted dimensions that characterise the nature of and level of change presented by an eco-innovation, including: sub-system, system, user development, user acceptance, product-service deliverable, product-service process, governance, and component.

It is difficult to identify why some environmental innovations - such as vertical gardens, car sharing schemes, recyclable carpets and traffic optimisation systems (OECD, European Commission, and Nordic Innovation Joint Workshop 2012) - may not be accepted and widely used, as a range of social, cultural, cognitive, technological, economic and political factors contribute that often interact with or reinforce one another and may be context-specific. Literature categorises these barriers to development and adoption in a range of ways, however they are largely categorised as being internal, external or technological in nature (CarrilloHermosilla, del Río González, and Könnöla 2009).

Internal barriers are described by Carrillo-Hermosilla, del Río González, and Könnöla (2009) as the characteristics of potential adopters; absorption capacity; and the attitudes and strategies towards change and environmental progress. External barriers include public policy; status of the economy; and availability of information; to the attitudes and awareness of stakeholders including consumers, suppliers, and competitors; financial and educational institutions; political and industrial associations; and the greater public. Technological barriers include financial considerations such as capital, and cost versus the potential benefits and costsavings; and the complexity of new innovations and compatibility with existing systems.

Despite primarily being characterised on the basis of environmental contribution, it is acknowledged that social and economic factors influence the depth of diffusion that environmental innovations realise. Social and cultural change in the form of new values and behaviours is considered to be 'one of the imperative conditions' in such a transformation (OECD, European Commission, and Nordic Innovation Joint Workshop 2012), and user behaviour plays a decisive role in the success of environmental innovation (Carrillo-Hermosilla, del Río González, and Könnöla 2009). Dust and Prokopoff (as cited in Shamiyeh 2010) agree, arguing that the best design solutions not only need to influence the way people think at mass scale, but also consider the macro and micro elements of all the systems it interacts with. Similarly, McAllum (2008) discusses the need for integrated thinking across several dimensions of society, including natural, financial, social, human and manufactured, in order to achieve immense change.

\section{Applying Environmental Innovation in the Built Environment}

It is acknowledged, 'that incremental 'business-as-usual' improvements alone are not likely to be sufficient' to tackle the significant global environmental challenges; and rather, more radical, disruptive and systemic forms of environmental innovation are key in the sustainable transformation towards a greener economy. The 'lock-in conditions' that are typical of governance institutions, however, can prevent the system-level changes required to support radical environmental innovation (Carrillo-Hermosilla, del Río González, and Könnöla 2009). Clearly a different approach is required that avoids 'lock-in' and encourages lateral thinking, both within government and across the built environment sector.

When considering opportunities to enable transformational environmental innovations, the economic, environmental and social aspects of sustainability are implicitly linked (Hargroves and Smith 2005, Smith, Hargroves, and Desha 2010). Researchers such as Bucolo and Wrigley (2011), Manzini (2007), Von Weizsäcker et al. (2009) believe that a social approach based on deep human insights across the whole of society will play a key role in addressing $21^{\text {st }}$ Century challenges, and a multi-disciplinary and collaborative approach is required. They urge engineers, 
designers and other built environment professionals to become active change agents developing collaborative visions, scenarios, ideas and enabling solutions to the urgent and complex issues society is facing. Furthermore, the researchers argue for interdisciplinary sharing of strengths to catalyse shifts in behaviour.

\section{Emerging Design Elements of Transformative Change}

Similarly, both built environment and design professionals appreciate that a 'whole systems' approach is key in enabling transformation. This section presents a number of emergent concepts in design that could be used to influence built environment sector practices and drive transformative change. These concepts include 'design thinking', 'design innovation', 'social innovation' and 'disruptive innovation'.

\section{Design Thinking}

Traditionally, design has been considered to be an aesthetically focused profession concerned with discrete artefacts, and designers were often engaged late in the product development process and thus had limited scope to add value. It is now widely accepted and understood, however, that design has the potential to contribute more strategically and considers a much broader and holistic view of the surrounding systems (Brown 2008, Bucolo, Wrigley, and Matthews 2012). Described as 'the union of design and strategy' (Bucolo, Wrigley, and Matthews 2012), this design capability is popularly referred to as 'design thinking' whereby deep human insights inform a reframing of an organisations value proposition and 'repositioning of the firm's focus' so as to deliver creative alternatives (Brown 2008, Bucolo and Wrigley 2011).

\section{Design Innovation}

Using a design thinking approach, design innovation takes into account a range of perspectives such as technology demands, user needs and business requirements - and presents radically new propositions (Bucolo and Matthews 2011). Similarly, in sustainability related fields, a triple bottom line approach emphasises the pursuit of a range of goals - ecological, social and economic - simultaneously. It is recognised, though, that balancing several considerations is difficult and Cannatelli, Masi and Molteni (as cited in Nicholls and Murdock 2012) observed that one of the three dimensions typically plays a driving role resulting in trade-offs between them. According to Hargroves and Smith (2005), however, it is possible to achieve 'no-major-tradeoffs' and the pursuit of one goal may actually contribute to the achievement of other goals resulting in 'win-win-win outcomes'. Dixon and Clifford (2007) describe a new breed of entrepreneur that are holistically driven by all three forces as 'ecopreneurs', and this type of innovator is described by Walley and Taylor (as cited in Dixon and Clifford 2007) as a "crucial change agent' in a greener approach to business.

In addition to human values, it is well recognised that the technology and business dimensions must also be considered as imperative elements of design innovation (as shown below in Figure 1) in order to ensure a product or process is not only usable and desirable, but also feasible and viable (Centre for Design Innovation n.d.). 


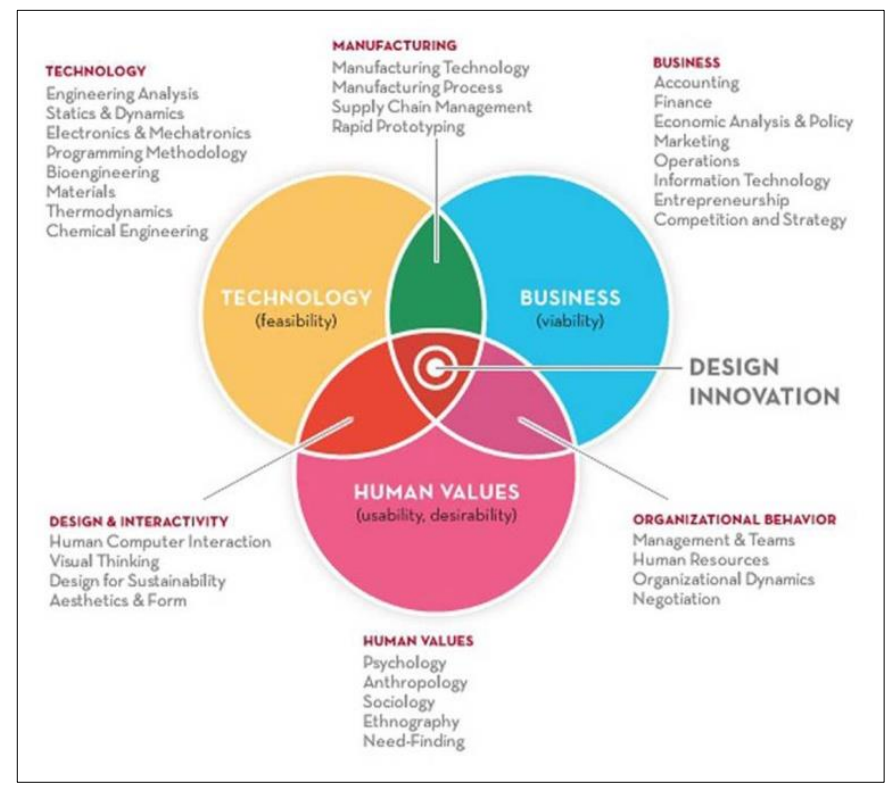

Figure 1: Three forces of design innovation

Source(s): Centre for Design Innovation n.d.

A core characteristic of design innovation is the focus on internal and external stakeholders, in a process akin to co-creation, which assists in the communication of value and subsequent broader acceptance of an alternative future vision (Bucolo and Matthews 2011). Bucolo and Matthews (2011) describe this concept as a process of grounding iterative stakeholder conversation around future propositions, so as to communicate value.

\section{Social Innovation}

Through considering human values and insights into people and their behaviours, Dust and Prokopoff (as cited in Shamiyeh 2010) believe that behavioural change can be achieved 'by inspiring people to embrace a system as a shareholder.' By letting 'the user close the loop,' they describe a dynamic system in which users can shift and influence the way it works and are thus active participants in changing the environment around them.

Nicholls and Murdock (2012) draw together a range of perspectives from various authors and consider 'social innovation' as, both, a process of 'recontextualization' and the creation of new structures and ideas with 'creative reconfiguration' (MacCallum et al., 2009 as cited in Nicholls and Murdock 2012) and societal change as a core driver. It is suggested that social innovation is capable of disrupting and reconfiguring systems on a macro level, and is described as a 'sixth wave' of modern macro-innovation (following five waves in modern history - from the 'Industrial Revolution' to 'The Age of Information and Telecommunications' - that are associated with a disruptive technology). Nicholls and Murdock (2012) classify three levels of social innovation (as shown below in Table 1).

Table 1: Levels of social innovation

\begin{tabular}{|c|l|l|l|}
\hline Level & \multicolumn{1}{|c|}{ Objective } & \multicolumn{1}{c|}{ Focus } & \multicolumn{1}{c|}{$\begin{array}{c}\text { Example Organization } \\
\text { (Sector) }\end{array}$} \\
\hline Incremental & $\begin{array}{l}\text { To address identified } \\
\text { market failures more }\end{array}$ & $\begin{array}{l}\text { Products and } \\
\text { services }\end{array}$ & $\begin{array}{l}\text { Kickstart (low-cost irrigation } \\
\text { foot pump), Aurolab (low-cost }\end{array}$ \\
\hline
\end{tabular}




\begin{tabular}{|l|l|l|l|}
\hline & $\begin{array}{l}\text { effectively: e.g. negative } \\
\text { externalities and } \\
\text { institutional voids }\end{array}$ & $\begin{array}{l}\text { intraocular lenses), Afghan } \\
\text { Learning Institute (female } \\
\text { education) }\end{array}$ \\
\hline Institutional & $\begin{array}{l}\text { To reconfigure existing } \\
\text { market structures and } \\
\text { patterns to create new } \\
\text { social value }\end{array}$ & Markets & $\begin{array}{l}\text { MPESA (mobile banking), } \\
\text { Institute for One World Health } \\
\text { ('orphan' drugs), Cafédirect } \\
\text { (Fair Trade) }\end{array}$ \\
\hline Disruptive & $\begin{array}{l}\text { To change the cognitive } \\
\text { frames of reference around } \\
\text { markets and issues to alter } \\
\text { social systems and } \\
\text { structures }\end{array}$ & $\begin{array}{l}\text { Politics (social } \\
\text { movements) }\end{array}$ & $\begin{array}{l}\text { Greenpeace (environmental } \\
\text { change), BRAC (micro- } \\
\text { finance), Tostan (human rights) }\end{array}$ \\
\hline
\end{tabular}

Source(s): Nicholls and Murdock 2012

Hubert et al. (2010) promote a similar view, distinguishing three broad categories of social innovation in terms of their reach across society. They describe a 'social demand' approach to grassroots social innovations as those directed toward vulnerable groups of society whose issues are not currently addressed; broader social innovations that focus on 'societal challenges' as a whole and blur social and economic boundaries; and a 'systematic change' approach that fundamentally shifts policies, strategies, attitudes, values, organisational structures, delivery systems, services and processes subsequently reshaping society.

The broadest reaching and systems-changing style of social innovation is generally referred to as 'disruptive social innovation' in which the change dynamics 'can be violent and rapid' (Nicholls and Murdock 2012).

\section{Disruptive Innovation}

Disruptive innovations were initially described by Bower and Christensen (1995) in the specific context of technological innovation. Disruptive technologies were differentiated from sustaining technologies which were described as offering customers something 'more or better in the attributes they already value,' as opposed to a disruptive form which presents 'a new and different package of attributes' for a currently unserved market (Bower and Christensen 1995, 45). The terminology has been widened to include technologies, products and business models; however there is debate as to whether these can collectively be described as 'disruptive innovations' or are in need of finer classification (Markides 2006).

Brown (2009) describes disruptive innovation as revolutionary in nature in that it creates entirely new markets with new products and users. A well-documented example of a potentially disruptive innovation that has not infiltrated society as successfully as anticipated, is the twowheeled transporter known as the Segway. Literature suggests that the creators failed to consider the larger ecosystem in which it would be a part of, and its use subsequently conflicted with local road and sidewalk regulations resulting in limited use (Brown 2009, Shamiyeh 2010).

\section{Learning From Design in the Built Environment}

The focus of existing and emerging design research appears to be in environmental innovation with more recent literature centred on low carbon innovation. Within built environment research, there is an increasing focus on GHG emissions and opportunities for whole of building approaches to performance improvement (Sustainable Built Environment National Research Centre 2012). Not yet represented in the literature, however, is enquiry as to how separate professions facing similar challenges may learn from each other. For example, industrial designers and construction project managers may be equally as concerned with minimising the amount of waste that is generated in their respective activities. There is a notable absence of literature exploring how design lessons could inform a step change towards low carbon 
operations in the Australian built environment sector (as shown diagrammatically by the first author below in Figure 2).

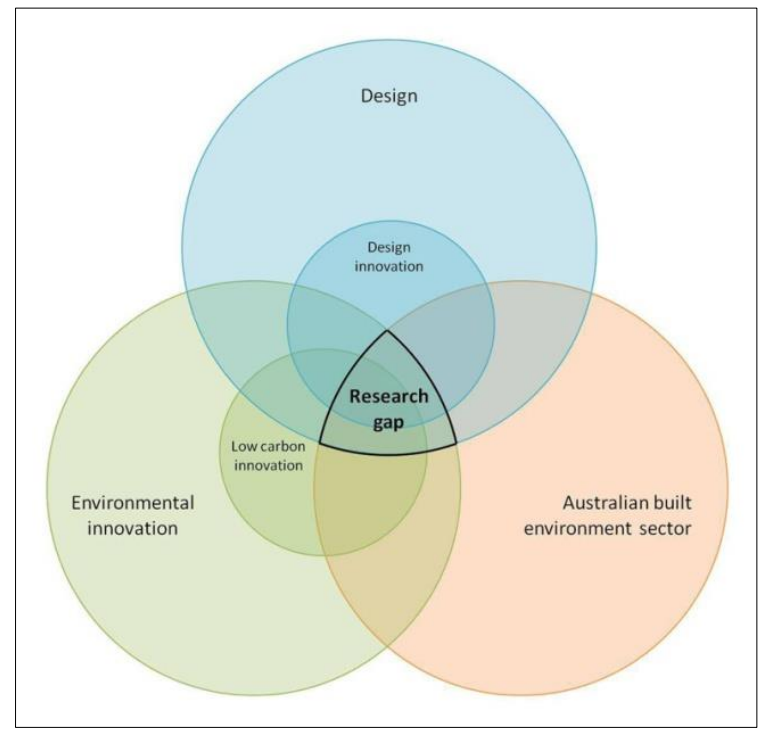

Figure 2: A diagrammatic representation of a research gap identified in the literature

It is clear from the emergent elements discussed in the previous section, that design has the potential to play a significant role in 'reshaping existing systems' (Carrillo-Hermosilla, del Río González, and Könnöla 2009) and transitioning the Australian built environment sector to low carbon operations. In exploring strategies to drive innovation in the Australian built environment sector, and recognising design 'as the ubiquitous capability for innovation' (Built Environment Industry Innovation Council 2012), there is an opportunity to embrace design leadership and establish a 'design champion' in the sector as an advocate for design-driven innovation.

In shifting from the incremental environmental innovation currently occurring in the Australian built environment sector, to a more radical and disruptive form capable of transforming the whole sector, there are opportunities for the traditionally engineering-oriented sector to learn from the design field in facilitating a shift to low carbon operation. Some examples of this include:

- Understanding the range of stakeholders in the whole built environment 'system', revealing the latent needs and reflecting on value propositions (making sure that new solutions are appropriate and desirable).

- Exploring a broad range of possibilities through creative ideation, divergent exploration and blue-sky thinking within the constraints of existing systems (such as retrofitting existing infrastructure).

- Solutions-based action and the iterative development of the contributory elements in realisation of that end goal (starting with the 'low carbon operation' goal, and establishing a path towards achieving the goal).

\section{Research Implications and Conclusion}

This paper has explored the potential for design to inform a strategy for significantly increasing the diffusion of environmental innovations - with a specific focus on reducing carbon emissions in the built environment sector. There are a number of design approaches that are emerging as opportunities for delivering sustainable solutions, and it is clear that there is potential for such 
application in the Australian built environment sector. It is anticipated that the interdisciplinary outcomes of this research will be of value across Government, industry and the education sector.

From these observations, a number of propositions for research towards this agenda arise, as summarised here:

- Sharing knowledge across disciplines in relation to whole system transformation may uncover new insights.

- Future research may explore what built environment professionals and designers, in particular, can learn from each other and their respective approaches. Specifically, an exploration in the field of design on the approaches and opportunities emerging for delivering sustainable solutions may be undertaken. In the built environment sector, an investigation into the current challenges in realising a transformational shift to low carbon operation may illuminate specific barriers.

- There may be a mutually beneficial relationship between environmental innovation and profitability in the built environment sector.

- Future research may explore specific environmental goals (such as a reduction in carbon emissions), the degrees to which profitability is maintained or increased, the characteristics of incremental through to radical styles of innovation in this context, and the variations across built environment sectors internationally.

- There may be specific innovation qualities and societal characteristics under which disruptive change towards low carbon operation occurs.

Future research may delve deeper into stakeholder perceptions, engagement barriers and opportunities, the skills, knowledge and new competencies that are needed to support 'green growth', and collaborative prospects between disciplines.

These propositions form the basis of a PhD enquiry into why the use of low carbon options is ad hoc and highly variable and how design thinking can be used in the Australian built environment industry to reduce carbon intensity. Specifically, the relationship between the technology, business and human dimensions will be considered in creating a suite of recommendations enabling a rapid and profitable transition to low carbon operation.

\section{Acknowledgement}

This research paper was undertaken as part of the first author's $\mathrm{PhD}$ studies and has been informed by Project 1.3: 'The Future of Roads: Reducing Environmental Pressures, Managing Carbon, and Considering Future Scenarios', under the Sustainable Built Environment National Research Centre (SBEnrc) Research Program 1: 'Greening the Built Environment.' The research was led by Professor Peter Newman (Curtin University) and managed by Mr Hargroves (Curtin University) and Dr Desha (QUT). 


\section{REFERENCES}

Arundel, A., and R. Kemp. 2009. Measuring eco-innovation. http://www.globeexpert.eu/quixplorer/filestorage/Interfocus/3-Economie/34-Places_Financieres/34-

SRCNL-UNU-MERIT/200903/Measuring_ecoa\%88\%92innovation.pdf.

Bower, J.L., and C.M. Christensen. 1995. Disruptive technologies: catching the wave: Harvard Business Review Video.

Brown, Tim. 2008. "Design Thinking." Harvard Business Review no. 86 (6):84-92.

Brown, Tim. 2009. Change by design: how design thinking transforms organizations and inspires innovation. New York, USA: HarperCollins Publishers.

Bucolo, Sam, and Judy H. Matthews. 2011. Design led innovation: exploring the synthesis of needs, technologies and business models. Paper read at Participatory Interaction Conference, at Sønderborg, Denmark.

Bucolo, Sam, and Cara Wrigley. 2011. Sustaining social innovation enterprises through a design led innovation framework. In Business Design Conference, edited by Jurgen Faust: CreateSpace Independent Publishing Platform.

Bucolo, Sam, Cara Wrigley, and Judy Matthews. 2012. "Gaps in Organizational Leadership: Linking Strategic and Operational Activities through Design-Led Propositions." Design Management Journal no. 7 (1):18-28.

Built Environment Industry Innovation Council. 2012. Final report to the Government: December 2012. edited by Innovation The Department of Industry, Science, Research and Tertiary Education (DIISRTE). Canberra, Australia: Commonwealth of Australia.

Carrillo-Hermosilla, J., P. del Río González, and T. Könnöla. 2009. Eco-innovation: When sustainability and competitiveness shake hands. Hampshire, UK: Palgrave Macmillan.

Centre for Design Innovation. Design Innovation. Institute of Technology Sligo n.d. Available from http://www.designinnovation.ie/what_innovation_sec1.html.

Christensen, Clayton M., Heiner Baumann, Rudy Ruggles, and Thomas M. Sadtler. 2006. "Disruptive Innovation for Social Change." Harvard Business Review no. 84 (12):94101.

Davis Langdon. Carbon tax implications on building life cycle costs 'significant' 2012. Available from http://www.theurbandeveloper.com/features/carbon-tax-implications-onbuilding-life-cycles-significant-davis-langdon/.

Dixon, Sarah E.A., and Anne Clifford. 2007. "Ecopreneurship - a new approach to managing the triple bottom line." Journal of Organizational Change Management no. 20 (3):326-345. doi: 10.1108/09534810710740164.

Fry, Tony. 2009. Design Futuring: sustainability, ethics and new practice. Sydney, Australia: University of New South Wales Press Ltd.

Hargroves, Karlson, and Michael Harrison Smith, eds. 2005. The Natural Advantage of Nations: business opportunities, innovations and governance in the 21 st century. London, UK: Earthscan.

Hubert, Agnès, Jean-Claude Thébault, Margaritis Schinas, Matteo Bonifacio, and Joep Konings. 2010. "Empowering people, driving change: Social innovation in the European Union." Bureau of European Policy Advisors (BEPA).

Manzini, Ezio. 2007. "Design Research for Sustainable Social Innovation." Design Research Now:233-245. doi: 10.1007/978-3-7643-8472-2_14.

Markides, Constantinos. 2006. "Disruptive Innovation: In Need of Better Theory." Journal of Product Innovation Management no. 23 (1):19-25. doi: 10.1111/j.15405885.2005.00177.x.

McAllum, Michael J. C. 2008. Designing better futures: rethinking strategy for a sustainable world. Bribie Island, Australia: GFN Press.

Nicholls, Alex, and Alex Murdock, eds. 2012. Social innovation: blurring boundaries to reconfigure markets. Hampshire, UK: Palgrave Macmillan. 
OECD, European Commission, and Nordic Innovation Joint Workshop. 2012. The future of ecoinnovation: the role of business models in green transformation. http://www.oecd.org/sti/innovationinsciencetechnologyandindustry/49537036.pdf.

OECD Innovation Strategy. 2009. Eco-Innovation in Industry - Enabling Green Growth. http://www.oecd.org/sti/innovationinsciencetechnologyandindustry/eco-

innovationinindustryenablinggreengrowth.htm.

Rennings, Klaus. 2000. "Redefining innovation: eco-innovation research and the contribution from ecological economics." Ecological Economics no. 32 (2):319-332. doi: 10.1016/S0921-8009(99)00112-3.

Shamiyeh, Michael, ed. 2010. Creating desired futures: how design thinking innovates business. Basel, Switzerland: Birkhäuser GmbH.

Smith, Michael Harrison, Karlson Hargroves, and Cheryl Desha. 2010. Cents and sustainability: securing our common future by decoupling economic growth from environmental pressures. London, UK: Earthscan.

State of the Environment 2011 Committee. 2011. Australia State of the Environment 2011: In Brief. edited by Environment Department of Sustainability, Water, Population and Communities. Canberra, Australia: Commonwealth of Australia 2011.

Stern, Nicholas. 2006. Stern Review on the Economics of Climate Change. London, UK: HM Treasury.

Sustainable Built Environment National Research Centre. 2011. SBEnrc Centre Brochure: Innovation underpinning Australia's built environment industry. Brisbane, Australia: Sustainable Built Environment Research Centre.

Sustainable Built Environment National Research Centre. 2012. Understanding the performance of green commercial buildings: a Sustainable Built Environment National Research Centre (SBEnrc) final industry report. Curtin University \& Queensland University of Technology.

Von Weizsäcker, Ernst, Karlson Hargroves, Michael Harrison Smith, Cheryl Desha, and Peter Stasinopoulos. 2009. Factor five: transforming the global economy through $80 \%$ increase in resource productivity. London, UK: Earthscan.

\section{ABOUT THE AUTHORS}

Ms Kimberley Wilson: Ms Kimberley Wilson is a researcher with The Natural Edge Project (TNEP), a collaborative partnership for research, education, and policy development on innovation for sustainable development. Kim graduated with a Bachelor of Design with First Class Honours from Queensland University of Technology in 2011. With a background in industrial design and sustainable development in urban infrastructure, Kim is currently completing her $\mathrm{PhD}$ focusing on design innovation in the built environment.

Dr Cheryl Desha: Dr Cheryl Desha is a Senior Lecturer in Sustainable Development, in the Science and Engineering Faculty at Queensland University of Technology, Brisbane. Cheryl has a degree in Engineering (Environmental, first class) and a $\mathrm{PhD}$ in rapid curriculum renewal, and is a Principal Researcher with The Natural Edge Project (TNEP).

Professor Sam Bucolo: Sam Bucolo is Professor of Design and Innovation at University of Technology Sydney. Sam is a leading academic and practitioner in the emerging field of design led innovation, and has led projects which have transformed businesses by embedding design capability.

Associate Professor Evonne Miller: Associate Professor Evonne Miller is Research Leader (Design), in the Creative Industries Faculty at Queensland University of Technology, Brisbane. Evonne is an environmental psychologist, whose research focuses on social sustainability. 
Mr Charlie Hargroves: Mr Charlie Hargroves is a Senior Research Fellow, in the Curtin University Sustainability Policy Institute (CUSP) at Curtin University, Perth. Charlie is a coauthor of five international books on sustainable development, along with Dr Desha, with two of the books ranked highly among the 'Top 40 Sustainability Books' in the world in 2010 by the Cambridge Sustainability Leaders Program. Charlie's research focuses on carbon structural adjustment, including areas of technology and process innovation, skills development and curriculum renewal, and behaviour change. 